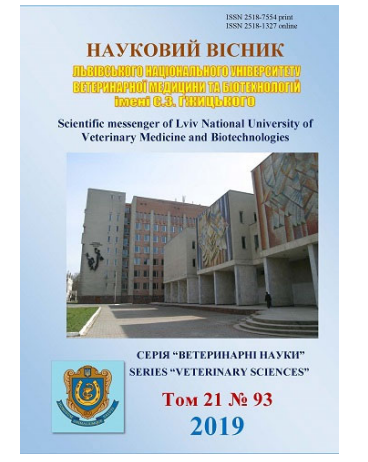

\section{Науковий вісник Яьвівського національного університету ветеринарної медицини та біотехнологій імені С.3. Гжицького. Серія: Ветеринарні науки}

Scientific Messenger of Lviv National University of Veterinary Medicine and Biotechnologies. Series: Veterinary sciences

ISSN 2518-7554 print ISSN 2518-1327 online doi: $10.32718 /$ nvlvet9326

http://nvlvet.com.ua

UDC 619:614.31:616-02/-033.1:637.513

\title{
The analysis of the dynamics of detection animal's invasive diseases during veterinary expertise
}

\author{
M.S. Khimich ${ }^{1}$, O.T. Piven ${ }^{1}$, O.M. Gorobey ${ }^{1}$, V.Z. Salata ${ }^{2}$, D.V. Freiuk ${ }^{2}$, O.V. Naidich ${ }^{3}$ \\ ${ }^{1}$ Odessa State Agrarian University, Odessa, Ukraine \\ ${ }^{2}$ Stepan Gzhytskyi National University of Veterinary Medicine and Biotechnologies Lviv, Ukraine \\ ${ }^{3}$ Odessa State Environmental University, Odessa, Ukraine
}

Article info

Received 12.02.2019

Received in revised form 14.03.2019

Accepted 15.03.2019

Odessa State Agrarian University, Panteleymonyvska Str., 13,

Odessa, 65012, Ukraine.

Tel.: +38-067-799-21-13

E-mail:khimichms@gmail.com

Stepan Gzhytskyi National University of Veterinary Medicine and Biotechnologies Lviv, Pekarska Str., 50, Lviv, 79010, Ukraine.

Odessa State Environmental University, Lvivska Str., 15, Odessa, 65016, Ukraine.
Khimich, M.S., Piven, O.T., Gorobey, O.M., Salata, V.Z., Freiuk, D.V., \& Naidich, O.V. (2019). The analysis of the dynamics of detection animal's invasive diseases during veterinary expertise. Scientific Messenger of Lviv National University of Veterinary Medicine and Biotechnologies. Series: Veterinary sciences, 21(93), 149-154. doi: 10.32718/nvlvet9326

The main direction of state policy regarding the guaranty safety and quality of animal products is the creation of conditions that are safe for human health during the production and sale of food raw materials. According to current legislation of Ukraine responsibility for the safety of food products placed on the manufacturer but government control plays an important role. This is especially true today, when almost $69.5 \%$ of meat is produced in private home farms. It is mainly sold in the agro-industrial markets. The State Service of Ukraine for Food Safety should perform the conditions of modern European regulation and base its activities on the basis of risk assessment. One of the risks are parasitosis, as their negative effect affects the health of millions of people in the world. In this cjnnection the purpose of the study was to analyze the dynamics of the identification of invasive diseases at the stages of slaughter of animals and the sale of slaughter products. Research material was reporting on veterinary medicine (Form № 5-vet and Form № 6vet) of a number of districts of Odessa region for 2014-2017. It was founded that 75943 animals were slaughtered in 2014-2017: 91.18\% pigs, $8.14 \%$ cattle and 0.68\% sheep. The analysis of the dynamics of slaughter, depending on its location, showed that from $41.85 \%$ to $99.81 \%$ of animals were slaughtered at courtyard. According to the results of veterinary-sanitary control and supervision during the slaughter for the studied years there were no cases of diseases. It was founded that 22617 animal's carcasses came to the agrofood markets of the regions for the years 2014-2017, among which $89.56 \%$ were pig carcasses, 10,11\% cattle carcasses and only $0.33 \%$ sheep. According to results of veterinary-sanitary examination in the conditions of SLVSE in the markets, specialists established 351 cases of diseases. In the study of pig carcasses 246 cases of diseases were detected: among them of non-communicable (45.93\%) and invasive (54.07\%) etiology (echinococcosis). Luring the expertise of cattle carcases was founded 96 cases of diseases: - dicroceliosis (98.96\%) and exinococcosis (1.04\%); during the expertise of sheep's carcases - 9 cases of diseases - dicroceliosis (66.67\%) and exinococcosis (33.33\%). Considering that during the reporting period, according to the results of veterinary-sanitary control and supervision during the slaughter of animals, no cases of diseases were detected, but at the same time the number of cases of detection of invasive diseases during veterinary-sanitary examination in SLVSE on markets constantly increases risk management at the stage of slaughter can be considered not sufficiently effective. Also, the results of our research indicate that the current system for managing the safety of slaughter products is still based primarily on the study of the final product. It does not take into account all possible risks at the previous stages of production. This system can't fully guarantee to consumer safety of products.

Key words: sloughter, products of sloughter, agrofood market, risk, invasive diseases, exinococcosis, dicroceliosis. 


\title{
Аналіз динаміки виявлення інвазійних хвороб тварин за проведення ветеринарно-санітарної експертизи
}

\author{
М.С. Хімич ${ }^{1}$, О.Т. Півень ${ }^{1}$, О.М. Горобей ${ }^{1}$, В.З. Салата ${ }^{2}$, Д.В. Фреюк ${ }^{2}$ О.В. Найдіч ${ }^{3}$ \\ ${ }^{1}$ Одеський державний аграрний університет, м. Одеса, Украӥна \\ ${ }^{2}$ Львівський національний університет ветеринарної медицини та біотехнологій імені. С.3. Гюицького, \\ м. Львів, Україна \\ ${ }^{3}$ Одеський державний екологічний університет, м. Одеса, Україна
}

\begin{abstract}
Основним напрямом державної політики щодо гарантованої безпечності та якості продуктів тваринного походження $\epsilon$ створення умов безпеки для здоров'я людей під час виробництва та реалізаиії продовольчої сировини. Згідно з чинним законодавством України відповідальність за безпечність харчової продукиії покладена на виробника, але важливу роль відіграє $i$ державний контроль. Особливо це актуально сьогодні коли майже 69,5\% м'яса виробляється у приватних селянських господарствах, що в переважній кількості реалізується на агропромислових ринках. Державна служба України з питань безпеки харчових продуктів повинна виконувати вимоги сучасної європейської регламентачї та організувати свою діяльність на основі засад оиінки ризиків, одним з яких є паразитози, адже їх негативний вплив відбивається на здоров"ї мільйонів людей у світі. В зв'язку з иим метою дослідження було проаналізувати динаміку виявлення інвазійних захворювань на етапах забою тварин $i$ реалізації продуктів забою. Матеріалом досліджень була звітність з питань ветеринарної медицини (Форма № 5-вет $i$ Форма № 6-вет) низки районів Одеської області за 2014-2017 роки. Встановлено, щзо за 2014-2017 роки в районах забито 75943 голів тварин, з яких 91,18\% становили свині, 8,14\% велика рогата худоба і 0,68\% - вівиі. Аналіз динаміки забою залежно від місия його проведення виявив, що від 41,85\% до 99,81\% забою тварин проводиться подвірно, а за результатами ветеринарносанітарного контролю $і$ нагляду - під час забою за дослідні роки не було виявлено жодного випадку хвороб. Встановлено, що за 2014-2017 роки на агропродовольчі ринки районів для реалізаиї надійшло 22617 туш тварин, з яких 89,56\% становили туші свиней, 10,11\% туші великої рогатої худоби і лише 0,33\% - туші овеиь. За результатами ветеринарно-санітарної експертизи в умовах ДЛВСЕ на ринках фахівиями було зафіксовано 351 випадок хвороб. Зокрема за дослідження туш свиней виявлено 246 випадків хвороби незаразної $(45,93 \%)$ та інвазійної (54,07\%) етіології, а саме ехінококоз; за експертизи туш ВРХ виявлено 96 випадків хвороб - дикроцеліоз (98,96\%) та ехінококоз (1,04\%); за експертизи туш овець - 9 випадків хвороб - дикроцеліоз (66,67\%) та ехінококоз $(33,33 \%)$. Враховуючи, що за звітний період за результатами ветеринарно-санітарного контролю $і$ нагляду під час забою тварин жодного випадку хвороб виявлено не було, а натомість кількість випадків виявлення інвазійних хвороб під час ветеринарно-санітарної експертизи в умовах ДЛВСЕ на агропромислових ринках невпинно зростає, систему управління ризиками на етапі забою можна вважати недостатньо ефективною. Також результати наших досліджень свідчать про той факт, щцо діюча в державі система управління безпечністю продуктів забою і досі трунтується передовсім на досліджені кінцевого продукту, не враховує всі можливі ризики на попередніх етапах виробнищтва і тим самим не може повністю гарантувати споживачу безпечність продукту.
\end{abstract}

Ключові слова: забій, продукти забою, агропродовольчий ринок, ризик, інвазійні хвороби, ехінококоз, дикрочеліоз.

\section{Вступ}

Основним напрямом державної політики щодо гарантованої безпечності та якості продуктів тваринного походження є створення умов безпеки для здоров'я людей під час виробництва та реалізації продовольчої сировини (Bukalova et al., 2016).

Згідно з чинним законодавством України основна відповідальність за безпечність та якість харчової продукції покладено на виробника. Але сьогодні основним виробником м'яса $є$ селянин. У приватних селянських господарствах виробляється майже 69,5\% м'яса, що в подальшому у переважній кількості реалізується на агропромислових ринках. У зв'язку з цим важливу роль відіграє державний контроль і нагляд на всіх етапах виробництва (Kasianchuk et al., 2015; Bohatko et al., 2016; Bukalova et al., 2016; Patrieva, 2016).

Державна служба України з питань безпечності харчових продуктів та захисту споживачів, виконуючи вимоги Європейської регламентації, повинна організовувати свою роботу на основі оцінки ризиків безпеки харчових продуктів (Bohatko et al., 2016; Patrieva, 2016).

Одним 3 вагомих факторів ризику є гельмінтози. За даними ВООЗ - сьогодні паразитарними захворю- ваннями уражено близько $2,5 \%$ населення. Згідно 3 повідомленням ФАО “Багатокритеріальний рейтинг для управління ризиками появи паразитів у харчових продуктах" та ряду авторів не останнє місце в їх поширенні відіграють продукти тваринного походження (Uspenskij, 2013; FAO/WHO, 2014; Koziarin et al., 2015; Yemets \& Yemets, 2016).

Мета та завдання дослідження. Враховуючи вищевикладене, метою нашого дослідження було проаналізувати динаміку виявлення інвазійних хвороб за результатами експертизи продуктів забою сільськогосподарських тварин (свині, велика рогата худоба, вівці), з вирішенням таких завдань:

- дослідити динаміку виявлення інвазій на етапі забою та первинної переробки;

- дослідити динаміку виявлення інвазій на етапі реалізації;

- визначити ефективність управління ризиками появи паразитів у м'ясі на етапах забою та первинної переробки і на етапі реалізації.

\section{Матеріал і методи досліджень}

Матеріалом наших досліджень була звітність 3 питань ветеринарної медицини (Форма № 5-вет і 
Форма № 6-вет) низки районів Одеської області за 2014-2017 роки, яку ми обробляли статистично.

\section{Результати досліджень}

На першому етапі наших досліджень ми проаналізували дані звітності щодо об'ємів забою тварин і результатів ветеринарно-санітарного контролю та нагляду під час забою.

Аналізом встановлено, що за 2014-2017 роки в районах проведено забій 75943 голів тварин, основну питому вагу серед яких склали свині - 91,18\%, значно менший об'єм припав на велику рогату худобу $8,14 \%$ і зовсім незначний відсоток склали вівці 0,68\% від загальної кількості тварин (рис. 1).

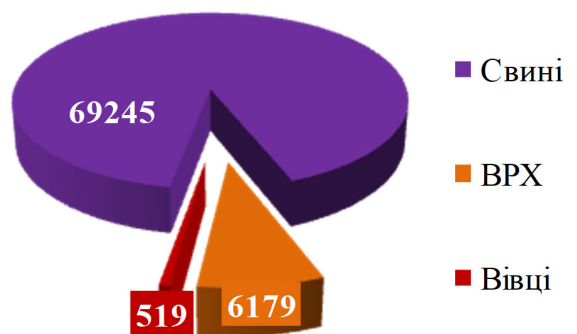

Рис. 1. Забито тварин в період 2014-2017 років, гол.

Згідно з чинним законодавством в Україні забій сільськогосподарських тварин, дозволено проводити на бійнях м'ясопереробних підприємств, на забійносанітарних пунктах господарств і подвірно (Bukalova et al., 2016; Zakon Ukrainy "Pro osnovni pryntsypy ta vymohy do bezpechnosti ta yakosti kharchovykh produktiv"). В зв'язку з цим ми детально вивчили динаміку забою тварин залежно від того, де проводився забій.

Встановлено (рис. 2), що 58,1\% свиней було забито в умовах м'ясопереробних підприємств, $41,85 \%$ - подвірно і лише $0,05 \%$ - на забійносанітарних пунктах господарств.

На бійнях МПП

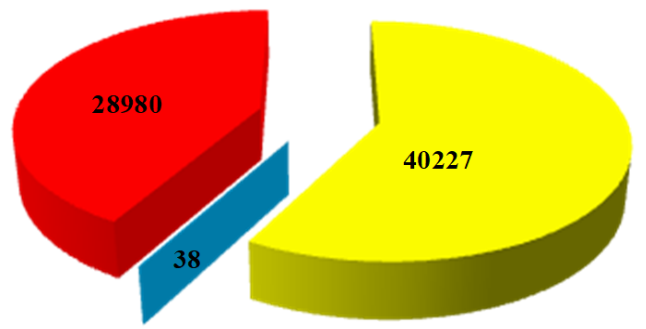

Рис. 2. Динаміка забою свиней залежно від місця забою, гол.

Щодо забою худоби (рис. 3), то він здебільшого проводився подвірно - 91,47\% тварин, в умовах м'ясопереробних підприємств було забито лише $8,32 \%$, а на забійно-санітарних пунктах господарств $0,21 \%$ тварин.

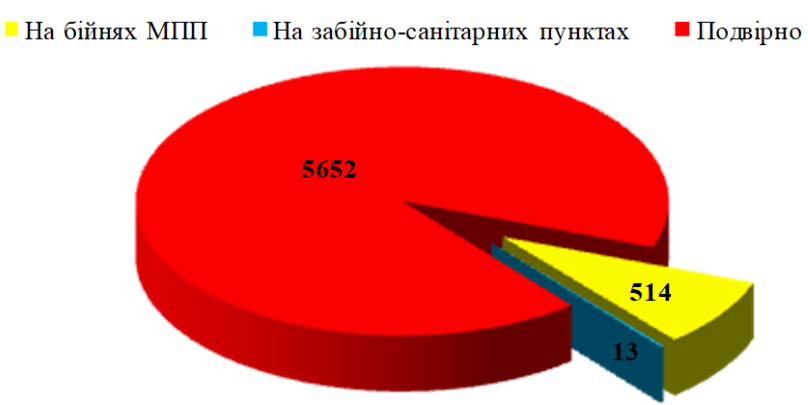

Рис. 3. Динаміка забою ВРХ залежно від місця забою, гол.

Динаміка щодо забою овець (рис. 4) виявилася такою: на МПП їх забій взагалі не проводиться, фактично весь забій (99,81\% тварин) відбувається подвірно.

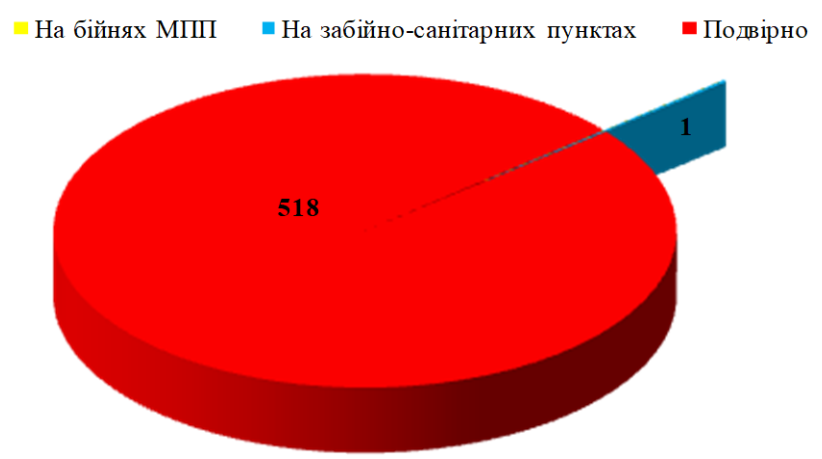

Рис. 4. Динаміка забою овець залежно від місця забою, гол.

Таким чином, аналіз отриманих даних щодо динаміки проведення забою свідчить, що від 41,85\% до 99,81\% забою тварин (залежно від виду), проводиться подвірно.

Відповідно до чинного законодавства (Pravyla peredzabiinoho veterynarnoho ohliadu tvaryn..., 2002; Bukalova et al., 2016) забій тварин допускається тільки за умови проведення ветеринарно-санітарного контролю i нагляду. Згідно 3 вивченою звітною документацією, всі без винятку тварини, які надходили на забій, проходили передзабійний огляд, а отримані продукти забою піддавали післязабійній ветсанекспертизі, за результатами яких за дослідні роки не було виявлено жодного випадку хвороб.

На другому етапі досліджень ми проаналізували дані звітності щодо об'ємів реалізації продуктів забою тварин на агропродовольчих ринках і результатів їх ветеринарно-санітарної експертизи в умовах державних лабораторій ветеринарно-санітарної експертизи (ДЛВСЕ) на ринках.

Встановлено (рис. 5), що за 2014-2017 роки на агропродовольчі ринки районів для реалізації надійшло 22617 туш тварин, основну питому вагу яких склали туші свиней - 89,56\%, значно менше надійшло туш ВРX - 10,11\% і лише $0,33 \%$ туш овець. 


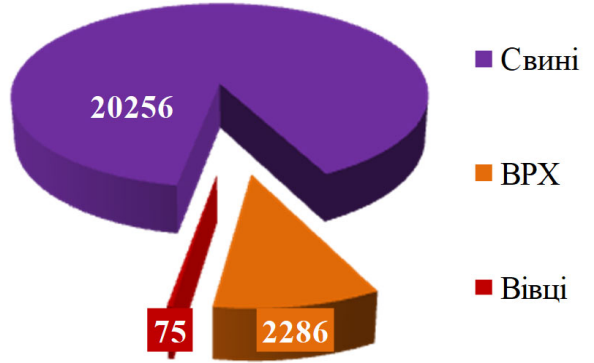

Рис. 5. Надійшло на реалізацію на агропродовольчі ринки в період 2014-2017 років, туш

Згідно зі звітною документацією всі туші, які надійшли на агропродовольчі ринки районів, пройшли ветеринарно-санітарну експертизу. Аналіз встановив, що за результатами проведеної фахівцями ДЛВСЕ на ринках експертизи туш було зафіксовано 351 випадок хвороб, зокрема за дослідження туш свиней - 246 випадків, ВРХ - 96 і овець - 9 випадків. Щодо етіології виявлених хвороб, то за експертизи туш свиней виявляли хвороби незаразної $(45,93 \%)$ та інвазійної (54,07\%), а за експертизи туш ВРХ і овець лише інвазійної етіології.

3 уваги на те, що нас насамперед цікавить питання щодо інвазійних хвороб тварин, ми окремо зупинились на вивчені динаміки їх виявлення. Встановлено (рис. 6), що за звітний період було зареєстровано всього 238 випадків інвазійних хвороб. Найбільше випадків виявлено під час експертизи туш свиней - 55,88\%, дещо менше за дослідження туш BPX - 40,34\% і найменше за експертизи туш овець $3,78 \%$.

Також ми спостерігаємо зростання кількості виявлення хвороб за експертизи туш ВРX з 18,75\% (випадків від загальної кількості, виявлених за дослідний період) у 2014 році до $35,42 \%$ у 2017 році. Натомість за експертизи туш свиней спостерігаємо зниження кількості випадків виявлення хвороб - 3 $32,33 \%$ випадків від загального їх числа за весь дослідний період у 2014 році до 20,3\% випадків у 2017 році.

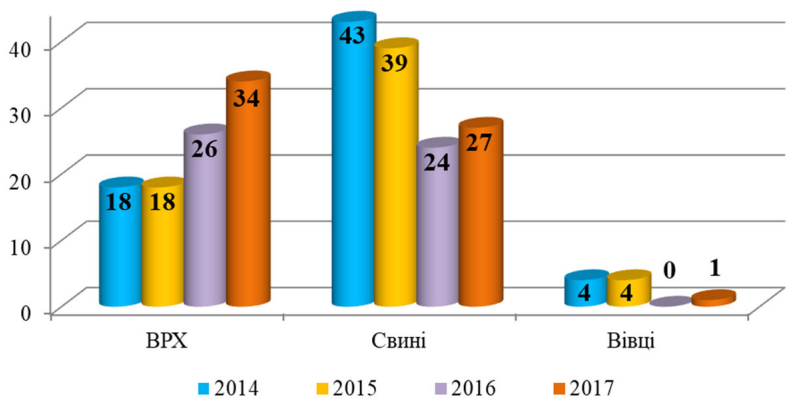

Рис. 6. Динаміка виявлення інвазійних хвороб під час ветеринарно-санітарної експертизи в ДЛВСЕ на ринках, випадків

Порівнюючи обсяги надходження туш тварин на реалізацію з кількістю випадків виявлення інвазійних хвороб, встановили, що найчастіше інвазійні хвороби реєстрували за експертизи туш овець - у 12,0\% випадків, рідше за експертизи туш ВРX - 4,2\% і найрідше за експертизи туш свиней - $0,66 \%$.

Надалі ми вивчили етіологію виявлених інвазійних хвороб тварин. Встановлено (рис. 7), що під час експертизи туш великої рогатої худоби виявляли дикроцеліоз та ехінококоз - 95 (98,96\%) і 1 (1,04\%) випадків відповідно; за експертизи туш свиней ехінококоз, у тушах овець - 6 випадків дикроцеліозу $(66,67 \%)$ та 3 випадки ехінококозу $(33,33 \%)$.

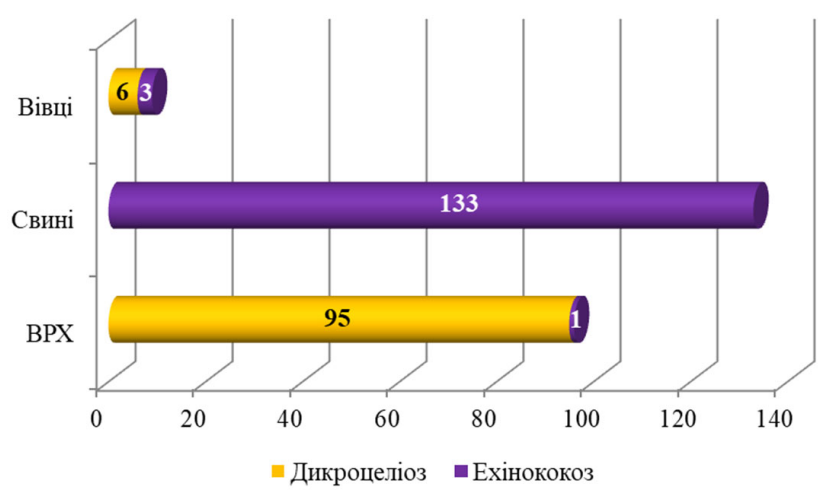

Рис. 7. Етіологія інвазійних хвороб виявлених під час ветеринарно-санітарної експертизи в ДЛВСЕ на ринках, випадків

Таким чином, ми бачимо, що під час ветеринарносанітарної експертизи на агропродовольчих ринках в період 2014-2017 років виявляли такі інвазійні захворювання, як ехінококоз (137 випадків) та дикроцеліоз (101 випадок).

\section{Обговорення}

Узагальнюючи дані аналізу звітної документації, ми акцентували увагу на декількох основних отриманих результатах.

Так, ми встановили, що забій тварин вирощених у приватних селянських господарствах, здебільшого проводиться подвірно i, що найважливіше, за результатами післязабійної ветсанекспертизи випадки виявлення хвороб не реєструються. Така ситуація викликає занепокоєння щодо якості здійснення контролю i нагляду під час забою. Подібних висновків щодо зниження безпечності продуктів забою за його подвірного проведення дійшли i Борисенко Н.Е. та Кроневальд О.В. (Borisenko \& Kroneval'd, 2015).

Результати аналізу реалізації продуктів забою на агропродовольчих ринках встановили значне зниження об'ємів надходження туш сільськогосподарських тварин на реалізацію, яке ми пов'язуємо зі зменшенням забою, що своєю чергою обумовлено зменшенням поголів'я тварин. Букалова Н.В. (Bukalova et al., 2016) і Свстаф'єва В.О. (Ievstafieva et al., 2018) зі співавторами спостерігають таку ж негативну динаміку в інших регіонах, зокрема на Київщини і Полтавщині, й пояснюють це також зменшенням поголів'я тварин.

За результатами аналізу ми встановили зростання 
кількості випадків виявлення хвороб, зокрема інвазійної етіології, під час проведення ветеринарносанітарної експертизи туш тварин у ДЛВСЕ на ринках. На провідну роль інвазій у вибракувані продуктів забою вказують у своїх роботах також ряд науковців (Borisenko \& Kroneval'd, 2015; Luzan \& Stetsenko, 2015; Bukalova et al., 2016; Kotelevych, 2017; Kotelevich, 2018).

Щодо етіології виявлених інвазій, то за дослідний період реєструвались ехінококоз та дикроцеліоз жуйних. Виявлення ехінококових уражень продуктів забою $є$ цілком закономірним, адже згідно з літературними даними його частіше реєструють саме у південних областях України, а Одеську область взагалі віднесено до “природних вогнищ” (Lytvynenko \& Pavlikovska, 2015; Yemets \& Yemets, 2016; Holovakha, 2018). Ураження великої і дрібної рогатої худоби дикроцеліями також часто реєструється на території України, а особливо в іiї південній частині (Bilopolska, 2012).

\section{Висновки}

Враховуючи, що за звітний період під час післязабійної ветсанекспертизи жодного випадку хвороб не виявляли, а натомість за ветеринарносанітарної експертизи в умовах ДЛВСЕ на агропродовольчих ринках кількість випадків виявлення хвороб, особливо інвазійної етіології, невпинно зростає, ми дійшли висновку про низьку ефективність контролю і нагляду на етапі забою. Водночас контроль на етапі реалізації ми вважаємо ефективним, пересвідчившись що й досі контроль безпечності та якості м'яса і м'ясопродуктів здебільшого грунтується на досліджені кінцевого продукту.

3 уваги на отримані результати ми вважаємо, що на території Одеської області такі гельмінтози тварин, як ехінококоз та дикроцеліоз жуйних, $є$ значущим фактором ризику, який необхідно враховувати у системі управління безпечністю продуктів забою тварин на всіх етапах виробництва.

\section{References}

Bilopolska, T.P. (2012). Dykrotselioz velykoi rohatoi khudoby $\mathrm{v}$ umovakh Pivdnia Ukrainy (poshyrennia, diahnostyka, likuvannia). Avtoreferat dysertatsii na zdobuttia stupenia kandydata veterynarnykh nauk. Kyiv (in Ukrainian).

Bohatko, N.M., Bukalova, N.V., Yatsenko, I.V., Serdiukov, Ya.K., \& Bohatko, A.F. (2016). Kontrol bezpechnosti miasa zabiinykh tvaryn ta ptytsi za yikh falsyfikatsii pry zberihanni ta realizatsii. Problemy zooinzhenerii ta veterynarnoi medytsyny, 32(2), 164-171. http://nbuv.gov.ua/UJRN/pzvm_2016_32\%282\%29_39 (in Ukrainian).

Borisenko, N.E., \& Kroneval'd, O.V. (2015). Vyjavlenie boleznej pri vetsanjekspertize produktov uboja zhivotnyh $\mathrm{v}$ altajskom krae. Vestnik Altajskogo gosudarstvennogo agrarnogo universiteta, 5(127), 122-126. https://cyberleninka.ru/article/n/vyyavleniebolezney-pri-vetsanekspertize-produktov-uboyazhivotnyh-v-altayskom-krae (in Russian).

Bukalova, N.V., Prylipko, T.M., \& Yakubash, R.A. (2016). Analiz patolohii produktiv zaboiu tvaryn, vyiavlenoi za provedennia veterynarno-sanitarnoi ekspertyzy v umovakh ahropromyslovoho rynku. Zbirnyk naukovykh prats Podilskoho derzhavnoho ahrarno-tekhnolohichnoho universytetu, 24(1), 33-43. http://nbuv.gov.ua/UJRN/ZnpPdatucg_2016_24\%281 $\% 29 \quad 7$ (in Ukrainian).

FAO/WHO (2014). Food and Agriculture Organization of the United Nations/World Health Organization. Multicriteria-based ranking for risk management of foodborne parasites. Microbiological Risk Assessment Series No. 23. Rome. 302 pp. Access mode: http://www.fao.org/publications/card/en/c/ee07c6aeb86c-4d5f-915c-94c93ded7d9e.

Holovakha, I.V. (2018). Epizootychna sytuatsiia z ekhinokokozu v Ukraini. Materialy mizhnarodnoi naukovo-praktychnoi konferentsii "Ahrarna osvita ta nauka: dosiahnennia, rol, faktory rostu”. m. Bila Tserkva, 43-44 (in Ukrainian).

Ievstafieva, V.O., Melnychuk, V.V., Kruchynenko, O.V., Mykhailiutenko, S.M., Korchan, L.M., \& Kovalenko, V.O. (2018). Monitorynhovi doslidzhennia shchodo yakosti ta bezpechnosti miasa tvaryn na terytorii Poltavskoi oblasti. Visnyk Poltavskoi derzhavnoi ahrarnoi akademii， 3, 132-136. http://nbuv.gov.ua/UJRN/ VPDAA 2018322 (in Ukrainian).

Kasianchuk, V.V., Berhilevych, O.M., Yefimova, O.M., \& Rotaienko, Yu. (2015). Systema prostezhuvanosti suchasna tekhnolohiia kontroliu $\mathrm{V}$ kharchovomu lantsiuhu dlia pidvyshchennia rivnia bezpechnosti kharchovykh produktiv. Veterynarna medytsyna Ukrainy, 2(228), 25-29. http://nbuv.gov.ua/UJRN/vetm_2015_2_9 (in Ukrainian).

Kasianchuk, V.V., Yefimova, O.M., Berhilevych, O.M., Skliar, O.I., \& Kusturov, V.B. (2015). Veterynarnosanitarnyi kontrol mikrobiolohichnykh pokaznykiv yalovychykh tush ta sanitarnykh umov vyrobnytstva. Scientific Journal "ScienceRise", 1, 3(6), 49-56. http://nbuv.gov.ua/UJRN/texc $2015 \quad 1 \% 283 \% 29 \quad 10$ (in Ukrainian).

Kotelevich, V.A. (2018). Kachestvo produktov zhivotnovodstva v Zhitomirskoj oblasti. Uchenye zapiski uchrezhdenija obrazovanija "Vitebskaja ordena "Znak Pocheta" gosudarstvennaja akademija veterinarnoj mediciny", 54(2), 95-98 (in Russian).

Kotelevych, V.A. (2017). Veterynarno-sanitarna otsinka yakosti ta bezpeky kharchovykh produktiv u Zhytomyrskomu rehioni. Naukovyi visnyk Lvivskoho natsionalnoho universytetu veterynarnoi medytsyny ta biotekhnolohii im. S.Z. Hzhytskoho, 19(78), 58-61. doi: 10.15421/nvlvet7812 (in Ukrainian).

Koziarin, I.P., Ivakhno, O.P., Chorna, V.V., \& Makhniuk, V.M. (2015). Helmintozy v Ukraini. Suchasnyi stan problemy. Hihiiena naselenykh mists, 66, 268-272. 
http://nbuv.gov.ua/UJRN/gnm_2015_66_44 (in Ukrainian).

Luzan, M.P., \& Stetsenko, N.V. (2015). Analiz rezultativ vetsanekspertyzy produktiv tvarynnytstva - obiektyvna informatsiia shchodo epizootychnoho stanu $\mathrm{v}$ pivnichno-skhidnomu rehioni Ukrainy. Veterynarna medytsyna Ukrainy, 1(227), 36-37. http://nbuv.gov.ua/UJRN/vetm_2015_1_13 (in Ukrainian).

Lytvynenko, O.P., \& Pavlikovska, T.M. (2015). Ekhinokokoz liudei i tvaryn v Ukraini. Veterynarna biotekhnolohiia, 26, 102-110 (in Ukrainian).

Patrieva, L.S. (2016). Perspektyvy mizhnarodnoho spivrobitnytstva Ukrainy u sferi bezpechnosti ta yakosti kharchovykh produktiv. Visnyk ahrarnoi nauky Prychornomoria, 3, 124-134. doi: 10.31521/2313-092X (in Ukrainian).

Pravyla peredzabiinoho veterynarnoho ohliadu tvaryn i veterynarno-sanitarnoi ekspertyzy miasa ta miasnykh produktiv. Nakaz vid 07.06.2002, № 28. [potochna redaktsiia vid 09.08.2013]. Rezhym dostupu: http://zakon2.rada.gov.ua/laws/show/z0524-02

(in Ukrainian).

Uspenskij, A.V. (2013). Optimizacija bezopasnosti pishhevyh produktov po parazitarnym zoonozam. Teorija i praktika parazitarnyh boleznej zhivotnyh, 14, 388-390 (in Russian).

Veterynarno-sanitarni pravyla dlia boien, zabiinosanitarnykh punktiv hospodarstv ta podvirnoho zaboiu tvaryn. Nakaz vid 14.01.2004, № 4. [potochna redaktsiia vid 08.10.2012]. Rezhym dostupu: https://zakon.rada.gov.ua/laws/show/z0121-04 (in Ukrainian).

Yemets, A.M., \& Yemets, M.A. (2016). Parasitosis as medical and veterinary problem. Visnyk Sumskoho natsio-nalnoho ahrarnoho universytetu, 11(39), 141146.

Zakon Ukrainy "Pro osnovni pryntsypy ta vymohy do bezpechnosti ta yakosti kharchovykh produktiv", vid 12.031997, № 771/97-VR [potochna redaktsiia vid 04.04.2018]. Rezhym dostupu: http://zakon3.rada.gov.ua/laws/show/771/97-vr (in Ukrainian). 